OPEN ACCESS

ISSN 25482254 (online)

ISSN 20893833 (print)

Edited by:

Mahardika Darmawan Kusuma

Wardana

Reviewedby:

Deni Adi Putrai

${ }^{*}$ Correspondence:

Endang Istikomah

endangistikomah@edu.uir.ac.id

Received: 29 Mei 2021

Accepted: 2 Juni 2021

Published: 4 Juni 2021

Citation:

Zetriuslita (2021) Improving Students'

Mathematics Communication Ability

Through Geogebra

Pedagogia: Jurnal Pendidikan. 10:2.

doi: 10.21070/pedagogia.v10vi2i.1266

\section{Improving Students' Mathematics Communication Ability Through Geogebra}

\section{Peningkatan Kemampuan Komunikasi Matematika Melalui Geogebra}

Zetriuslita $^{1}$, Nofriandi ${ }^{2}$, Endang Istikomah ${ }^{3 *}$

Fakultas Keguruan dan Ilmu Pendidikan, Universitas Islam Riau, Indonesia

The purpose of this study was to determine the improvement of students' matematical communication skills thorugh Geogebra. The research method use is quasi experiment. The sample used in this study was the second semester students of TA. 2018/2019. The instruments used in this research were about mathematical communication skills test. The results showed that the value of sig. of $0,000<0,05$. The conclusion obtained is that the mathematical communication skills of student in the experimental class are better than increasing the mathematical communication skills of students in the control class.

Keywords: Ability, Mathematical Communication, Geogebra

Tujuan penelitian ini adalah untuk mengetahui peningkatan kemampuan komunikasi matematika melalui Geogebra. Metode penelitian yang digunakan eksperimen quasi. Sampel yang digunakan dalam penelitian ini adalah mahasiswa semester 2 TA. 2018/2019. Instrumen yang digunakan dalam penelitian ini adalah soal tes kemampuan komunikasi matematis. Hasil penelitian menunjukkan bahwa nilai sig. sebesar $0,000<0,05$. Kesimpulan yang diperoleh yaitu kemampuan komunikasi matematis mahasiswa pada kelas eksperimen lebih baik dari pada peningkatan kemampuan komunikasi matematis mahasiswa pada kelas kontrol.

Kata Kunci: Kemampuan, Komunikasi Matematis, Geogebra 


\section{PENDAHULUAN}

Matematika merupakan salah satu mata kuliah yang dipelajari oleh mahasiswa dalam menempuh pendidikan di perguruan tinggi. Dalam proses pembelajaran matematika mahasiswa seringkali mengalami kesulitan dalam memecahkan persoalan matematika dan mengkomunikasikan gagasan, padahal kemampuan komunikasi matematika merupakan salah satu upaya untuk menentukan pencapaian pemahaman mahasiswa terhadap materi yang disampaikan oleh Dosen. Dalam proses perkuliahan, komunikasi memiliki peranan penting karena mencakup kemampuan mahasiswa untuk mengkomunikasikan konsep, pemecahan masalah, dan menemukan solusi. Artinya mahasiswa memiliki peranan penting dalam perkuliahan untuk berbagi pendapat dan gagasannya, kesempatan untuk berbicara, menulis, serta mendengarkan materi yang disampaikan oleh Dosen dalam proses perkuliahan Yuliardi et al. (2017). Ketika seseorang sedang dalam pemecahan masalah matematika maka siswa sedang membangun keterampilan matematika lainnya seperti kemampuan pemahaman, kemampuan representasi matematika, dan kemampuan lainnya Saragih et al. (2018).

Berdasarkan pengamatan peneliti sebagai salah satu dosen matematika di Fakultas Keguruan Ilmu Pendidikan Universitas Islam Riau diperoleh data bahwa, kemampuan komunikasi mahasiswa dalam menyampaikan hasil pemikirannya dalam proses perkuliahan masih rendah. Mahasiswa cenderung pasif dalam perkuliahan, sehingga kurang adanya komunikasi. Selanjutnya pembelajaran kurang dapat mengekspresikan kemampuan komunikasi matematisnya dan soal-soal yang diberikan masih merupakan soal-soal rutin dengan kata lain belum ada indikasi soal HighOrder Mathematical Thinking, serta mahasiswa belum pernah menggunakan perangkat lunak interaktif dalam pembelajaran pada matakuliah Geometri Analit Bidang dan Ruang. Hal ini mengakibatkan mahasiswa kesulitan dalam memaknai persoalan matematika sehingga tidak dapat memecahkan persoalan matematika dengan baik.

Adapun salah satu solusi yang peneliti tawarkan untuk meningkatkan kemampuan komunikasi matematis adalah dengan menggunakan salah satu perangkat lunak interaktif yang dapat digunakan dalam proses perkuliahan yaitu GeoGebra. Ada empat aspek yang ditawarkan oleh perangkat lunak matematika (termasuk GeoGebra) salah satunya adalah Konektivitas, artinya membuka peluang dalam pembelajaran matematika, GeoGebra dapat digunakan oleh pendidik untuk alat komunikasi sebagai bahan ajar Zilinskiene et al. (2014). Program ini memiliki fitur perangkat lunak geometri dinamis, sistem aljabar komputer dan juga spreadsheet dan semuanya terintegrasi dalam satu paket GeoGebra Belgheis et al. (2018).

GeoGebra merupakan software yang dikembangkan oleh Markus Hohenwarter pada tahun 2001, dan bisa secara bebas di download dari www.GeoGebra.org. Aljabar dan geometri merupakan inti dari GeoGebra Bhagat et al. (2014). Karakteristik utama yang membedakan GeoGebra dengan perangkat matematika yang lain adalah dapat dianggap sebagai sistem aljabar komputer di satu sisi lain sebagai perangkat lunak geometri Ismail et al. (2017). GeoGebra memiliki semua karakteristik essensial yang seharusnya dimi- liki oleh perangkat lunak pendidikan, GeoGebra bisa mengubah representasi simbolik menjadi geometris dan sebaliknya Khalil et al. (2017). Dengan demikian menurut Supriadi (2015) mahasiswa dapat mengorganisasi pemikiran matematisnya baik secara lisan maupun tulisan.

Selain itu, GeoGebra memungkinkan mahasiswa untuk aktif dalam perkuliahan materi aljabar dan geometri Arbain et al. (2015). Selanjutnya Nopiyani et al. (2016) menyatakan GeoGebra memungkinkan mahasiswa siswa untuk aktif dalam membangun pemahaman geometri dan aljabar. Perangkat lunak ini memungkinkan mahasiswa untuk membuat representasi sederhana objek matematika, sehingga memudahkan mahasiswa untuk menemukan, memecahkan, dan membuat representasi matematis dari gagasan yang telah dimiliki oleh setiap mahasiswa. Salah satu cara terbaik untuk meningkatkan pemahaman pelajar yang lebih baik adalah dengan menggunakan perangkat lunak dinamis yang disebut GeoGebra Safrida et al. (2018). Ide utama menggunakan GeoGebra ke dalam pengajaran dan pembelajaran sehari-hari adalah memberikan kesempatan bagi mahasiswa berbagai keterampilan dan skill matematika untuk memahami konsep yang lebih baik dan mendorong mereka untuk memahami matematika dengan cara baru yang menarik Majerek (2014). Senada dengan itu, Putrawan et al. (2014) berpendapat bahawa komponen GeoGebra dapat memancing komunikasi matematika menjadi lebih baik dan dapat meningkatkan hasil belajarnya. Lebih lanjut Stosic (2015) menyatakan bahwa dengan penerapan teknologi pendidikan, peserta didik dapat secara mandiri menguasai materi pembelajaran, untuk memilih ketepatan kerja, mengulang materi dan mengetahui kemajuannya.

Berdasarkan latar belakang di atas, penelitian ini difokuskan pada peningkatan kemampuan komunikasi matematis mahasiswa melalui Geogebra pada matakuliah Geometri analit bidang dan ruang. Adapun tujuan penelitian ini untuk mengkaji peningkatan kemampuan komunikasi matematis mahasiswa melalui Direct Instruction berbantuan geogebra dan pembelajaran konvensional.

\section{METODE}

Penelitian ini merupakan penelitian quasi eksperimen/ eksperimen semu Creswell (2014);Cohen et al. (2007) yang bertujuan untuk memperoleh data kuantitatif tentang kemampuan komunikasi matematis mahasiswa yang mendapat pembelajaran dengan Direct Instruction berbantuan geogebra dan mahasiswa yang mendapat pembelajaran konvensional. Desain yang digunakan kelompok kontrol nonekivalen/untreated control group design with pretest and posttest Setyosari (2010). Populasi dalam penelitian ini adalah mahasiswa semester dua TA. 2018/2019 pendidikan matematika FKIP UIR. Sedangkan pemilihan sampel dalam penelitin ini dengan teknik cluster random sampling Sugiyono (2011). Penelitian ini melibatkan dua kelas yaitu kelas eksperimen dan kelas kontrol dimana kedua kelas diberikan pretest, kemudian diberikan perlakuan yang berbeda dan yang terakhir diberikan posttest.

Variabel penelitian yang digunakan adalah variabel bebas 
dan variabel terikat. Variabel bebas dalam penelitian ini adalah Geogebra dan variabel terikatnya adalah kemampuan komunikasi matematis.Instrument yang digunakan dalam penelitian ini adalah instrumen tes berbentuk soal uraian untuk mengukur kemampuan komunikasi matematis mahasiswa. Data yang diperoleh dari hasil tes kemampuan komunikasi melalui pretes maupun postes dianalisis secara statistik dengan menggunakan program software SPSS versi 20 dan Microsoft Excell 2007. Data dianalisis dengan cara membandingkan skor mahasiswa sebelum dan setelah diberi perlakuan. Besarnya peningkatan sebelum dan sesudah pembelajaran dihitung dengan rumus gain ternormalisasi yang dikembangkan oleh Hake (1998) sebagai berikut:

$$
\text { Gain Ternormalisasi }(g)=\frac{\text { skor posttest }- \text { skor pretest }}{\text { skor ideal }- \text { skor pretest }}
$$

Kriteria indeks gain seperti pada Tabel 1

[Table 1 about here.]

Peneliti melakukan pengujian normalitas dan homogenitas dari data kelas eksperimen dan kelas kontrol serta melakukan uji kesamaan dua rerata menggunakan uji statistik parametrik, yaitu uji Independent-Samples t-test.

\section{HASIL DAN PEMBAHASAN Hasil}

\section{a. Analisis Data Pretes dan Postes Kemampuan Komunikasi Matematika Mahasiswa}

Sebelum dilakukan uji perbedaan rata-rata, maka diteliti terlebih dahulu normalitas dan homogenitas data penelitian sebagai uji asumsi dasar penelitian, berdasarkan hasil uji normalitas didapatkan hasil seperi berikut:

\section{[Table 2 about here.]}

Uji pretest kemampuan komunikasi matematis mahasiswa menunjukkan bahwa sig. $<0,05$, maka dapat disimpulkan bahwa data kemampuan komunikasi matematis kelas eksperimen maupun kelas kontrol tidak berdistribusi normal. Karena pengujian statistik parametrik tidak terpenuhi, pengujian dilanjutkan dengan ujian kesamaan, menggunakan statistik non parametrik yaitu Uji Mann-Whitney.

\section{[Table 3 about here.]}

Berdasarkan Uji Mann-Whitney diperoleh nilai sig. sebesar 0,833, karena nilai sig.> 0,05 berarti Ho diterima. Sehingga, dapat disimpulkan bahwa terdapat kesamaan rerata data pretest antara kelas eksperimen dan kelas kontrol pada kemampuan komunikasi matematis mahasiswa. Selanjutnya, kelas eksperimen dan kelas kontrol diberikan perlakuan berbeda melalui pembelajaran Geogebra. Setelah diberikan perlakuan maka dilakukan postest terhadap kelas eksperimen dan kelas kontrol. Berikut ini diteliti terlebih dahulu normalitas dan homogenitas data penelitian postest sebagai uji asumsi dasar penelitian.

\section{[Table 4 about here.]}

Berdasarkan hasil pengujian normalitas terhadap data postes mahasiswa, diperoleh nilai sig. $>0,05$, maka dapat disimpulkan bahwa data postes kelas eksperimen dan kelas kontrol berdistribusi normal, sehingga data kemampuan komunikasi matematis kelas kontrol dan kelas kontrol adalah data normal. Karena data postes berdistribusi normal, maka dilanjutkan dengan uji homogenitas varians data postest menggunakan uji levene, terhadap kemampuan komunikasi matematis data postest sebagai berikut.

\section{[Table 4 about here.]}

Berdasarkan hasil pengujian normalitas terhadap data postes mahasiswa, diperoleh nilai sig. $>0,05$, maka dapat disimpulkan bahwa data postes kelas eksperimen dan kelas kontrol berdistribusi normal, sehingga data kemampuan komunikasi matematis kelas kontrol dan kelas kontrol adalah data normal. Karena data postes berdistribusi normal, maka dilanjutkan dengan uji homogenitas varians data postest menggunakan uji levene, terhadap kemampuan komunikasi matematis data postest sebagai berikut.

\section{[Table 5 about here.]}

Berdasarkan hasil pengujian homogenitas data postes mahasiswa diperoleh sig. sebesar 0,026, karena nilai sig. < 0,05 berarti Ho ditolak. Sehingga, dapat disimpulkan bahwa data pencapaian (postes) kemampuan komunikasi matematis kelas eksperimen dan kelas kontrol tidak bervariansi homogen. Prosedur selanjutnya yaitu untuk mengetahui perbedaan rerata pencapaian (posttest) kemampuan komunikasi matematis dilakukan dengan Uji-t' sebagai berikut.

\section{[Table 6 about here.]}

Berdasarkan uji t' data postes mahasiswa, diperoleh sig. sebesar 0,000. Karena nilai sig $<0,05$. Karena nilai sig. $<0,05$, artinya Ho diterima. Kesimpulan yang diperoleh yaitu pencapaian komunikasi matematis mahasiswa kelas eksperimen lebih baik dari pada pencapaian kemampuan komunikasi matematis mahasiswa kelas kontrol.

\section{b. Analisis Data N-Gain Kemampuan Matematis Mahasiswa}

Berikut ini dilakukan uji normalitas sebagai asumsi dasar melakukan penelitian.

\section{[Table 7 about here.]}

Uji pretest kemampuan komunikasi matematis mahasiswa menunjukkan bahwa sig. $<0,05$, maka dapat disimpulkan bahwa data peningkatan kemampuan komunikasi matematis kelas eksperimen maupun kelas kontrol tidak berdistribusi normal. Karena pengujian statistik parametrik tidak terpenuhi, pengujian dilanjutkan dengan uji kesamaan, menggunakan statistik non parametrik yaitu Uji Mann-Whitney. 
[Table 8 about here.]

Berdasarkan hasil pengujian Mann-Whitney, diketahui nilai sig, sebesar 0,000 karena nilai $s i g<0,05$, artinya peningkatan (N-Gain) kemampuan komunikasi matematis mahasiswa kelas eksperimen lebih baik dari pada peningkatan kemampuan komunikasi matematis pada kelas kontrol. Dapat disimpulkan bahwa, peningkatan kemampuan komunikasi matematis kelas eksperimen lebih baik dari pada peningkatan kemampuan komunikasi kelas kontrol.

\section{Pembahasan}

Berdasarkan hasil analisis uji t' data penelitian komunikasi matematis mahasiswa diperoleh nilai sig. sebesar 0,000. Karena nilai sig. $<0,05$, artinya terdapat perbedaan rerata kemampuan komunikasi matematis antara kelas eksperimen dan kelas kontrol. Selanjutnya, berdasarkan hasil pengujian pada Tabel 7, diperoleh nilai probabilitas atau sig (two tailed) sebesar $0,000<0,05$, Sehingga Ho diterima, kesimpulan yang diperoleh yakni peningkatan (N-Gain) kemampuan komunikasi matematis pada kelas eksperimen lebih baik dari pada peningkatan kemampuan komunikasi matematis mahasiswa pada kelas kontrol.

Hasil ini memungkinkan karena melalui pembelajaran Geogebra mahasiswa difasilitasi dalam mengkontruksikan konsep matematika dan merepresentasikan gagasan yang dimilikinya, mahasiswa yang kesulitan dalam menggunakan Geogebra akan bertanya kepada dosen atau temannya yang lain yang sudah mengerti, pada saat pembelajaran melalui Geogebra. Pada saat itulah terjadi suatu komunikasi antara mahasiswa dan secara bersamaan akan membentuk suatu komunikasi matematis. Sehingga, dengan memulainya suatu komunikasi antara mahasiswa satu dengan yang lain, hal ini memungkinkan untuk meningkatkan kemampuan komunikasi matematis mahasiswa, karena antusiasnya dalam memahami dan mengoperasikan Geogebra dalam pembelajaran melalui Geogebra. Selain kemampuan komunikasi mahasiswa dapat meningkat, ternyata menurut hasil penelitian Oktaria et al. (2016) kemampuan representatasi matematis mahasiswa juga dapat meningkat. Lebih rinci Hanafi (2017) dalam penelitiannya memperoleh bahwa dengan menggunakan software GeoGebra dapat visualisasi objek materi geometri materi rotasi secara detail.

\section{KESIMPULAN}

Berdasarkan hasil penelitian dan pembahasan di atas, dapat disimpulkan bahwa peningkatan kemampuan komunikasi matematis mahasiswa kelas eksperimen lebih baik dari pada peningkatan kemampuan komunikasi matematis kelas kontrol. Dari penelitian ini peneliti menyarankan kepada para pendidik khususnya pembelajaran matematika dapat mencoba atau mengaplikasikan software Geogebra dalam proses pembelajaran khususnya pada materi yang abstrak.

\section{UCAPAN TERIMAKASIH}

Terimakasih peneliti ucapkan kepada pihak Kementerian Riset dan Teknologi DIKTI yang telah memberikan dana hibah penelitian sehingga terselesaikan penelitian ini. Kemudian terimakasih pula kepada pihak universitas terutama lembaga LPPM UIR yang telah membantu memberikan berbagai macam informasi terkait pelaksanaan penelitian sehingga mempermudah peneliti untuk menyelesaikan proses penelitian.

\section{REFERENCES}

Arbain, Z., \& Nurbiha, A. S. (2015). The Effects of GeoGebra on Students Achievement. Procedia Social and Behavioral Sciences, 209

Belgheis, S., \& Rozemalliza, K. (2018). The Intention to use GeoGebra in The Teaching of Mathematics Among Malaysian Teachers. Malaysian Online Journal of Educational Technology, 6 (1), 199

Bhagat, K. K., \& Chun, Y. C. (2014). Incorporating GeoGebra into Geometry Learning-A Lesson From India. Eurasia Journal of Mathematics, Science \& Technology Education, 11 (1), 79

Cohen, L, Manion, L \& Morrison, K (2007).Research methods in education.Companion Website.Sixth Edition.

Creswell, J.W (2014). Research design.qualitative, quantitative and mixed method approaches. Forth Edition. California.

Hake, R.R. (1998). Interactive-engagement Versus Traditional Method: A SixThousand-Student Survey Of Mechanics Test Data For Introductory Physics Course. American Journal of Physics, 66, 1, pp. 64-74.

Hanafi, M., Wulandari, K. N., \& Rizki Wulansari. (2017). Transformasi Geometri Rotasi Berbantuan Software Geogebra. Fibonacci: Jurnal Pendidikan Matematika dan Matematika, 3(2), 93-102.

Ismail, Z., \& Syairatul, N. A. R. (2017). Learning 2-Dimensional and 3Dimensional Geometry with GeoGebra: Which Would Students Do Better?. International Journal on Emerging Mathematics Education (IJEME), 1 (2),

Khalil, M., dkk. (2018) The Development of Mathematical Achievement in Analytuc Geometry of Grade-12 Students thriugh GeoGebra Activities. EURASIA Journal of Mathematics, Science and Technology Education, 14 (4)

Majerek, D. (2014). Application of GeoGebra for Teaching Mathematics. Advances in Sciences and Techology Research Journal, 8 (24)

Nopiyani, D., Turmudi, T., \& Prabawanto, S. (2016). Penerapan pembelajaran matematika realistik berbantuan geogebra untuk meningkatkan kemampuan komunikasi matematis siswa SMP. Mosharafa: Jurnal Pendidikan Matematika, 5(2), 45-52.

Oktaria, M. , Alam, A. K., \& Sulistiawati. (2016). Penggunaan Media Software GeoGebra untuk Meningkatkan Kemampuan Representasi Matematis Siswa SMP Kelas VIII. Jurnal Matematika Kreatif-Inovati, 7 (1), 108-116.

Putrawan, A. A., Suharta, I.G.P, \& Sariyas (2014). Pengembangan Perangkat Pembelajaran Matematika dengan Pendekatan Scientific Berbantuan GeoGebra dalam Upaya Meningkatkan Keterampilan Komunikasi dan Aktivitas Belajar MAtematika Siswa Kelas VIII SMP. Jurnal Pendidikan Universitas Pendidikan Ganesha, 3(1), 1-13.

Safrida, L. N., Susanto, S., \& Ambarwati, R. (2018). Integrating GeoGebra into Geometry Learning: A Lesson from Traditional Osing House Structure. The International Conference on Mathematical Analysis, Its Applications and Learning, 2018

Saragih, D. I.., Ani, M., \& Mukhtar. (2018). Analysis of Eight Grade Students' Mathematical Problem Solving Ability based on Geogebra-assisted Learning Approach. IOSR Journal of Research \& Method in Education (IOSR-JRME), 8 (4)

Setyosari, P. (2010). Metode Penelitian Pendidikan dan Pengembangan. Jakarta: Prenada Media Group.

Stosic, Lazar. (2015). The Importance Of Educational Technology In Teaching. (IJCRSEE) International Journal of Cognitive Research in Science, Engineering and Educatio, 3(1), 111-114.

Sugiyono. 2011. Statistika untuk Penelitian. Bandung: Alfabeta.

Supriad, Nanang. (2015). Pembelajaran Geometri Berbasis Geogebra Sebagai Upaya Meningkatkan Kemampuan Komunikasi Matematis. Al-Jabar: Jurnal Pendidikan Matematika, 6(2), 99 - 109. 
Yuliardi, R., \& Casnan. (2017). Mathematic Learning Assisted by GeoGebra Software to Improve SMK Student's Spatial Ability and Mathematical Communication. Unnes Journal of Mathematical Education 6 (1), 122

Zilinskiene, i., \& Muhammed, D. (2014). Use of Geogebra in Primary Math Education in Lithuania: An Exploratory Study from Teacher's Perspective. Informatics of Educations, 14 (1), 1
Conflict of InterestStatement:The authorsdeclare thattheresearch wasconducted in the absence of any commercial or financial relationships that could be construed as a potential conflict of interest.

Copyright $@ 2021$ Endang Istikomah. This is anopen-access article distributed under the terms of the Creative Commons Attribution License (CC BY). The use, distributionorreproduction in other forums is permitted, provided the original author(s) and the copyright owner(s) are credited and that the original publication in this journal is cited, in accordance with accepted academic practice. No use, distribution or reproduction is permitted which does not comply with these terms. 


\section{LIST OF TABLES}

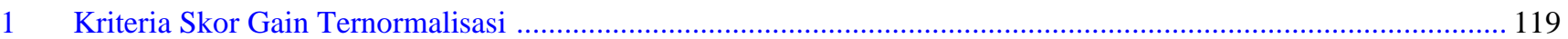

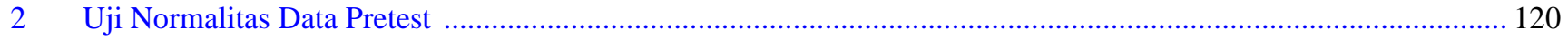

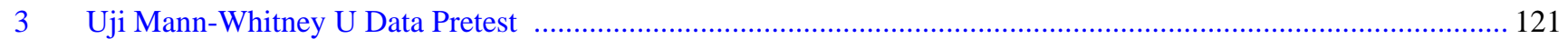

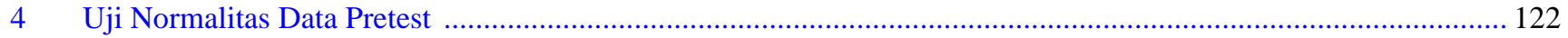

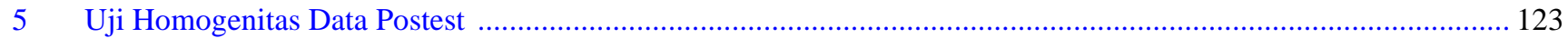

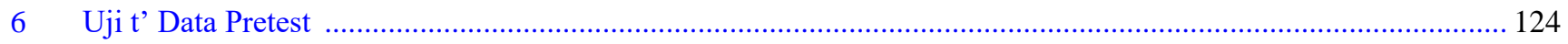

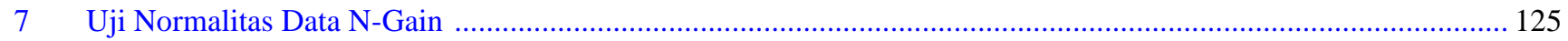

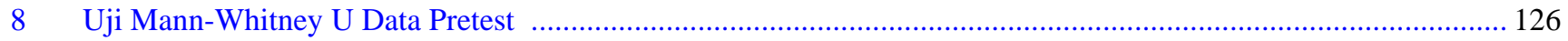


TABLE1/Kriteria Skor Gain Ternormalisasi

Skor Gain

$g>0,7$

$0,3<g \geq 0,7$

Interpretasi

$g \leq 0,3$

Tingg

Sedang

Rendah 
TABLE2/Uji Normalitas Data Pretest

\begin{tabular}{lllll}
\hline & \multicolumn{4}{c}{ Test of Normality } \\
\cline { 2 - 5 } & Statictic & Shapiro-Wilk & Sig. \\
\hline Pretest_Eksperimen & .888 & 42 & .001 & Ho \\
Pretest_Kontrol & .866 & 42 & .000 & Ditolak \\
\hline Liliefors Significance Correction & & & & Ditolak \\
\hline
\end{tabular}


TABEL 3/ Uji Mann-Whitney U Data Pretest

\begin{tabular}{lll}
\hline & \multicolumn{1}{c}{ Test Statistic ${ }^{\mathbf{a}}$} & No \\
\hline Mann-Whitney U & Nilai_Pretest & \\
Wilcoxon W & 858.500 & \\
Z & 1761.500 & Diterima \\
Asymp, Sig. (2-tailed) & -.211 & \\
\hline a. Grouping Variable: Kelas & .833 & \\
\hline
\end{tabular}


$\underline{\text { TABEL 4/ Uji Normalitas Data Pretest }}$

Test of Normality

Statictic

Pretest_Eksperimen

.888

Shapiro-Wilk

Pretest_Kontrol

.866

Sig.

.626

Ho

42

42

.119

Diterima 
$\underline{\text { TABEL 5/ Uji Homogenitas Data Postest }}$

Nilai_Postest

Levene Statistic

Test of Normality

5.167

$\mathrm{df1}$

df2

Sig.

.026

Ho

81

Ditolak 
TABEL 6/ Uji t' Data Pretest

Levene's Test for

$\mathrm{F}$

Nilai_Postes

Equal variances assumed

Equal variances not assumed
Equality of Variances

5.694

5.694

t-test for Equality of Means

Sig. $T$

Sig.

T

10.614

\begin{tabular}{ll}
$\mathrm{df}$ & Sig. (2-tailed) \\
\hline 82 & .000 \\
\hline 72.766 & .000
\end{tabular}


TABEL 7/ Uji Normalitas Data N-Gain

Test of Normality

\begin{tabular}{lccccc}
\hline & & & & \\
\cline { 2 - 4 } & Statictic & Df & Shapiro-Wilk & Ho \\
Gain_Eksperimen & .936 & 42 & .018 & Ditolak \\
Gain_Kontrol & .940 & 42 & .029 & Ditolak \\
\hline C. Liliefors Significance Correction & & & & &
\end{tabular}


TABEL 8 /Uji Mann-Whitney U Data Pretest

Test Statistic ${ }^{a}$

$$
\text { Nilai_Gain }
$$

87.500

990.500

$-7.161$

.000
$\mathrm{Ho}$

Diterima

Asymp, Sig. (2-tailed)

b. Grouping Variable: Kelas 